\title{
Inhibitory effect of hot-water extract of quince (Cydonia oblonga) on immunoglobulin E-dependent late-phase immune reactions of mast cells
}

\author{
Takeshi Kawahara • Tatsuhiro Iizuka
}

Received: 3 November 2010/ Accepted: 23 November 2010/Published online: 26 January 2011

(C) Springer Science+Business Media B.V. 2011

\begin{abstract}
We evaluated the effect of a crude hotwater extract (HW) of quince (Cydonia oblonga Miller) fruit on immunoglobulin E (IgE)-dependent late-phase immune reactions of mast cells using in vitro system. Mast cell-like RBL-2H3 cells were treated with quince $\mathrm{HW}$ and late-phase reaction was then induced by stimulation with IgE + Antigen. Quince HW reduced the elevation of interleukin-13 and tumor necrosis factor- $\alpha$ expression level. Furthermore, quince HW suppressed these cytokine expressions of mouse bone marrow-derived mast cells (BMMCs), a normal mast cell model. Leukotriene $\mathrm{C}_{4}$ and prostaglandin $\mathrm{D}_{2}$ production in BMMCs after 1 and $6 \mathrm{~h}$ of stimulation, respectively, were also reduced by treating the cells with quince $\mathrm{HW}$. We found that the induction of intracellular cyclooxygenase (COX)-2 expression but not COX-1 expression in BMMCs was reduced by quince HW. These results suggest that quince HW has an inhibitory effect on broad range of the late-phase immune reactions of mast cells.
\end{abstract}

Keywords Quince - Mast cell - Late-phase reaction - Leukotriene $\mathrm{C}_{4}$. Prostaglandin $\mathrm{D}_{2}$. Cyclooxygenase

T. Kawahara $(\bowtie) \cdot$ T. Iizuka

Laboratory of Food Bioscience, Faculty of Agriculture, Shinshu University, 8304, Minamiminowa, Kamiina, Nagano 399-4598, Japan

e-mail: tkawafb@shinshu-u.ac.jp

\author{
Abbreviations \\ Ag Antigen \\ BMMC Bone marrow-derived mast cell \\ COX Cyclooxygenase \\ ELISA Enzyme-linked immunosorbent assay \\ FBS Fetal bovine serum \\ FceRI High-affinity IgE receptor \\ FITC Fluorescein isothiocyanate \\ GAPDH Glyceraldehyde-3-phosphate \\ dehydrogenase \\ HW Hot-water extract \\ IgE Immunoglobulin E \\ IL Interleukin \\ LT Leukotriene \\ NSAID Nonsteroidal anti-inflammatory drug \\ PBS Phosphate-buffered saline \\ PE Phycoerythrin \\ PG Prostaglandin \\ RT-PCR Reverse transcription-polymerase chain \\ reaction \\ SD Standard deviation \\ TNF Tumor necrosis factor
}

\section{Introduction}

Type I allergy is an immediate-type inflammatory disease characterized by immunoglobulin $\mathrm{E}$ (IgE)induced detrimental reactions of the immune system 
caused by environmental substances. Allergic reactions such as asthma, eczema, and, rhinitis have increased in recent years as a result of the modern industrial and hygienic ways of life in industrial countries. The symptoms of immediate-type allergies are caused by the action of mast cells and basophils (Stone et al. 2010). These cells are hematopoietic cell-derived immunocompetent cells that express of high-affinity $\operatorname{IgE}$ receptor (FceRI) on their surface. Cross-linking of FceRI by attaching IgE with allergen-derived multivalent antigen $(\mathrm{Ag})$ triggers biochemical cascades that lead to degranulation, that is, the exocytotic release of granule-stored chemical mediators (Metzger 1978). The resultant inflammation caused by these mediators within minutes of exposure to $\mathrm{Ag}$ is termed "early-phase" in immediate-type allergic reactions (Williams and Galli 2000).

On the other hand, recent studies have focused on the subsequent "late-phase" immune reactions that occur several hours after the exposure to Ag (Metz et al. 2007). In late-phase reactions, inflammatory cytokines, including interleukin (IL)-13 and tumor necrosis factor (TNF)- $\alpha$, are synthesized (Gordon and Galli 1990, 1991; Burd et al. 1995). These cytokines contribute to the development of allergic symptoms through the mechanisms of class switching for IgE production from plasma cells (Cameron et al. 2000) and activation of phospholipase $\mathrm{A}_{2}$ (Kang et al. 2008). The release of arachidonic acids by the action of activated phospholipase $\mathrm{A}_{2}$ in response to the degranulation signalling further leads to the formation of metabolites, including leukotrienes (LTs) and prostaglandins (PGs; Seeds and Bass 1999). These metabolites increase vascular permeability and initiate smooth muscle contraction (Dahlén et al. 1981, 1983; Giles and Leff 1988). Not only do these proinflammatory substances have the physiological functions, but also they also recruit several immune cells such as eosinophils, macrophages, $\mathrm{T}$ cells, and natural killer $\mathrm{T}$ cells to the inflammatory site, resulting in progression of the morbidity and severity of inflammatory allergic symptoms (Pawankar et al. 2003). Therefore, approaches designed to alleviate the onset of late-phase reactions of mast cells are considered to be effective in preventing immediatetype allergic symptoms.

Recently, we reported the anti-allergic effect of a crude hot-water extract (HW) of quince on immediate allergic model NC/Nga mice (Shinomiya et al. 2009). Quince HW notably alleviated the severity of atopic dermatitis-like skin lesions with degranulation of serum IgE. This study indicates that quince HW has some suppressive effects on immediate-type allergic reaction including the physiological function of mast cells.

In this study, we investigated the effect of quince HW on the IgE- and Ag-induced elevation of inflammatory cytokine expressions and production of lipid mediators in mast cells.

\section{Materials and methods}

Preparation of quince HW

Quince HW was prepared as described previously (Shinomiya et al. 2009). In brief, the peel, pulp and seeds of quince fruits were cut into pieces, and then boiled in hot water for $1 \mathrm{~h}$. After filtering the extract through a layer of cloth, the filtrate was centrifuged at $5,000 \times g$ for $30 \mathrm{~min}$. The resulting supernatant was concentrated to $450 \mathrm{~mL}$ in a rotary evaporator (RE 400A-W; Yamato, Tokyo, Japan) at $40{ }^{\circ} \mathrm{C}$, and freeze-dried to obtain quince HW.

Cells

The rat basophilic leukemia RBL-2H3 cell line was purchased from the Health Science Research Resources Bank (Osaka, Japan). The cells were maintained in complete RPMI1640 medium (Nissui Pharmaceutical, Tokyo, Japan) containing 10\% heatinactivated fetal bovine serum (FBS; Equitech-Bio, Kerrville, TX, USA), 2 mM L-glutamine (Invitrogen Life Technologies, Carlsbad, CA, USA), 100 IU/mL of penicillin, and $100 \mu \mathrm{g} / \mathrm{mL}$ of streptomycin in a humidified atmosphere of $5 \% \mathrm{CO}_{2} / 95 \%$ air at $37{ }^{\circ} \mathrm{C}$.

Mice

Specific pathogen-free DBA/2 Cr mice aged 8 weeks were purchased from Japan SLC (Shizuoka, Japan) and housed at $23 \pm 3{ }^{\circ} \mathrm{C}$ under a 12-h light/dark cycle. The mice were used at 6-8 weeks of age. All the animal protocols used in this study were approved by the Committee for Animal Experiments of Shinshu University. 
Preparation and cultivation of mouse bone marrow-derived mast cells (BMMCs)

BMMCs were prepared from 6 to 8 -week-old mice according to a previously described method (Lee et al. 2005). Mice were killed by cervical dislocation and their intact femurs were aseptically harvested. Bone marrow cells were obtained by repeatedly flushing the femurs with RPMI1640 medium containing $100 \mathrm{IU} / \mathrm{mL}$ penicillin and $100 \mu \mathrm{g} / \mathrm{mL}$ streptomycin. The cells thus obtained were washed twice with the same medium by centrifugation at $700 \times g$ for $10 \mathrm{~min}$. The centrifuged cells were suspended in complete RPMI1640 medium supplemented with 10\% FBS, $1 \mathrm{mM}$ non-essential amino acids (Invitrogen), $5 \mathrm{ng} / \mathrm{mL}$ recombinant mouse IL-3 (Peprotech, Rocky Hill, NJ, USA), $50 \mathrm{mM}$ 2-mercaptoethanol, $100 \mathrm{IU} / \mathrm{mL}$ penicillin, and $100 \mu \mathrm{g} / \mathrm{mL}$ streptomycin. They were then cultured at a density of $1 \times 10^{5}$ cells/ $\mathrm{mL}$ in a humidified atmosphere of $5 \% \mathrm{CO}_{2} / 95 \%$ air at $37{ }^{\circ} \mathrm{C}$. After $4-5$ weeks, the cells were subjected to flow cytometric analysis for the evaluation of cell surface FceRI and c-Kit expression and to a $\beta$-hexosaminidase release assay, as described below.

Induction of $\operatorname{lgE}$-mediated stimulation

RBL-2H3 cells or BMMCs $\left(4 \times 10^{5}\right.$ cells $\left./ \mathrm{mL}\right)$ were treated with indicated concentration of quince $\mathrm{HW}$ for $24 \mathrm{~h}$. The cells were harvested and washed twice with HEPES-Tyrode buffer ( $137 \mathrm{mM} \mathrm{NaCl}, 5.6 \mathrm{mM}$ glucose, $2.7 \mathrm{mM} \mathrm{KCl}, 0.5 \mathrm{mM} \mathrm{NaH} \mathrm{PO}_{4}, 1.0 \mathrm{mM}$ $\mathrm{CaCl}_{2}$ and $10 \mathrm{mM}$ HEPES at $\mathrm{pH}$ 7.3) containing $0.1 \%$ bovine serum albumin. The washed cells were suspended in the same buffer in a centrifuge tube (BM Equipment, Tokyo, Japan) at a density of $1 \times 10^{7}$ cells $/ \mathrm{mL}$. The cells were stimulated by using mouse monoclonal anti-dinitrophenyl IgE antibody (clone SPE-7; Sigma, St. Louis, MO, USA) as IgE and dinitrophenyl-labeled human serum albumin (Sigma) as Ag under indicated condition. After stimulation, the supernatant collected by centrifugation. The resultant pellet was washed twice with phosphate-buffered saline (PBS; $\mathrm{pH}$ 7.2) and stored at $-80{ }^{\circ} \mathrm{C}$ until use.

In parallel with this assay, the growth and viability of quince $\mathrm{HW}$-treated BMMCs were evaluated by counting the cells with a hematocytometer after staining with trypan blue.

Reverse transcription-polymerase chain reaction (RT-PCR)

RBL-2H3 cells and BMMCs $\left(2 \times 10^{6}\right.$ cells $)$ were degranulated using $2 \mu \mathrm{g} / \mathrm{mL} \mathrm{IgE}+10 \mathrm{ng} / \mathrm{mL} \mathrm{Ag}$ for the indicated time, and total RNA was extracted from them by using TRIzol reagent (Invitrogen) according to the manufacturer's protocol. The extracted RNA $(1 \mu \mathrm{g})$ was reverse-transcribed in a thermal cycler (PTC-200; MJ Research, Waltham, MA, USA) with $1 \mathrm{mM}$ of each dNTP, $10 \mathrm{pmol} / \mu \mathrm{L}$ of oligo $(\mathrm{dT})_{18}$ primers, and $25 \mathrm{U} / \mu \mathrm{L}$ of M-MLV reverse transcriptase (Invitrogen) at $42{ }^{\circ} \mathrm{C}$ for $50 \mathrm{~min}$. The resulting cDNA was subjected to polymerase chain reaction with a SYBR Premix Ex Taq (Takara Bio, Shiga, Japan) and $10 \mathrm{pmol} / \mu \mathrm{L}$ of the primers listed in Table 1 . The PCR consisted of 1 cycle of preheating $\left(95^{\circ} \mathrm{C}, 10 \mathrm{~s}\right)$ and 45 cycles of denaturation $\left(95^{\circ} \mathrm{C}\right.$,

Table 1 Primer sequences used in this study

\begin{tabular}{|c|c|c|c|c|}
\hline \multirow[t]{2}{*}{ Target } & \multicolumn{2}{|l|}{ Sequence } & \multirow{2}{*}{$\begin{array}{l}\text { Product } \\
\text { size (bp) }\end{array}$} & \multirow{2}{*}{$\begin{array}{l}\text { Accession } \\
\text { number }\end{array}$} \\
\hline & Forward & Reverse & & \\
\hline Rat IL-13 & 5'-ACCAGAAGACTTCCCTGTGC-3' & 5'-TGCAACTGGAGATGTTGGTC-3' & 105 & L26913 \\
\hline Rat TNF- $\alpha$ & 5'-ACGATGCTCAGAAACACACG- $3^{\prime}$ & 5'-GAGACAGCCTGATCCACTCC-3' & 168 & BC107671 \\
\hline Rat $\beta$-actin & 5'-GTCGTACCACTGGCATTGTG-3' & 5'-TCTCAGCTGTGGTGGTGAAC-3' & 180 & ВC063166 \\
\hline Mouse IL-13 & $5^{\prime}$-CAGCATGGTATGGAGTGTGG-3' & 5'-AGGCCATGCAATATCCTCTG-3' & 117 & NM_008355 \\
\hline Mouse TNF- $\alpha$ & 5'-TAGCCAGGAGGGAGAACAGA-3' & 5'-TTTTCTGGAGGGAGATGTGG-3' & 127 & M13049 \\
\hline Mouse COX-1 & 5'-CTTCTCCACGATCTGGCTTC-3' & $5^{\prime}$-GCTGCAGGAAATAGCCACTC-3' & 176 & ВC005573.1 \\
\hline Mouse COX-2 & $5^{\prime}$-TTGGGGAGACCATGGTAGAG-3' & 5'-CATTGATGGTGGCTGTTTTG-3' & 231 & M94967 \\
\hline Mouse GAPDH & 5'-CACTGAGCATCTCCCTCACA-3' & 5'-GTGGGTGCAGCGAACTTTAT-3' & 111 & ВC096042 \\
\hline
\end{tabular}


$5 \mathrm{~s}$ ), primer annealing $\left(55^{\circ} \mathrm{C}, 10 \mathrm{~s}\right)$, and extension $\left(72{ }^{\circ} \mathrm{C}, 20 \mathrm{~s}\right)$ and was performed in a Thermal Cycler Dice Real Time System TP800 (Takara Bio) or a StepOnePlus Real Time PCR System (Life Technologies, Foster City, CA, USA). The PCR products were analyzed by the $\Delta \Delta \mathrm{Ct}$ method using TP800 software (Takara Bio) or StepOne software (Life Technologies). The amount of the PCR product was normalized against the gene expression level of $\beta$-actin and glyceraldehyde-3-phosphate dehydrogenase (GAPDH) for rat and mouse gene expressions, respectively.

Enzyme-linked immunosorbent assay (ELISA)

The level of histamine, $\mathrm{LTC}_{4}$ and $\mathrm{PGD}_{2}$ in supernatant was evaluated by a competitive ELISA. Supernatant of BMMCs was collected after stimulation with $2 \mu \mathrm{g} / \mathrm{mL} \mathrm{IgE}+100 \mathrm{ng} / \mathrm{ml} \mathrm{Ag}$ at indicated time from the cells by centrifugation at $10,000 \times g$ for $5 \mathrm{~min}$. The resultant supernatant was subjected to ELISA using a Histamine EIA kit (SPI-Bio technology, Montigny-le-Bretonneux, France), LTC $_{4}$ EIA kit (Cayman Chemical, Ann Arbor, MI, USA) and $\mathrm{PGD}_{2}$ EIA kit (Cayman Chemical) in accordance with the manufacturer's recommendation, respectively.

Flow cytometric analysis

The surface expression of c-Kit and FceRI on BMMCs was determined by flow cytometric analysis. For FceRI labeling, $1 \times 10^{6} \mathrm{BMMCs}$ were washed

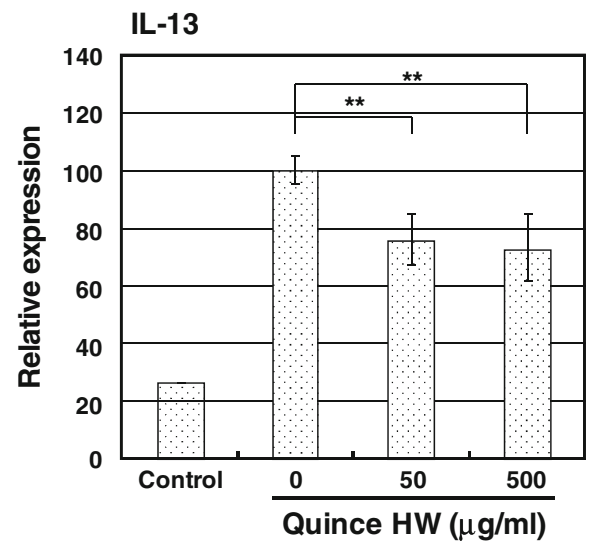

Fig. 1 Effects of quince HW on cytokine expression in RBL$2 \mathrm{H} 3$ cells. The expression of all cytokines was analyzed after $2 \mathrm{~h}$ of stimulation with $\mathrm{IgE}+\mathrm{Ag}$. Control means no stimulus (without $\mathrm{IgE}+\mathrm{Ag}$ ). Data are represented as the relative mean twice with PBS and treated with $0.125 \mu \mathrm{g} / \mathrm{mL}$ fluorescein isothiocyanate (FITC)-labeled anti-mouse Fc $\varepsilon R I \alpha$ Armenian hamster IgG (clone MAR-1; eBioscience, San Diego, CA, USA) and phycoerythrin (PE)-labeled anti-mouse c-Kit rat IgG (clone 2B8; eBioscience) at room temperature for $30 \mathrm{~min}$. FITClabeled Armenian hamster IgG isotype control (clone eBio299Arm; eBioscience) and PE-labeled rat IgG isotype control (clone eB149/10H5; eBioscience) were used as a negative control. After the cells were stained, they were washed with PBS and analyzed using flow cytometer (FACSCalibur; BD Biosciences San Jose, CA, USA). All data were analyzed using the CellQuest Pro software (BD Biosciences).

Statistical analysis

The data were statistically analyzed using a twotailed Student's $t$ test. A $p$ value of less than 0.05 was considered statistically significant.

\section{Results}

Effect of quince HW on IgE-induced elevation of cytokine expressions in RBL-2H3 cells

The effects of quince HW treatment on the $\operatorname{IgE}+$ Ag-induced mRNA expressions in RBL-2H3 cells are shown in Fig. 1. After $2 \mathrm{~h}$ of stimulation with $\mathrm{IgE}+\mathrm{Ag}$, gene expression of IL-13 and TNF- $\alpha$

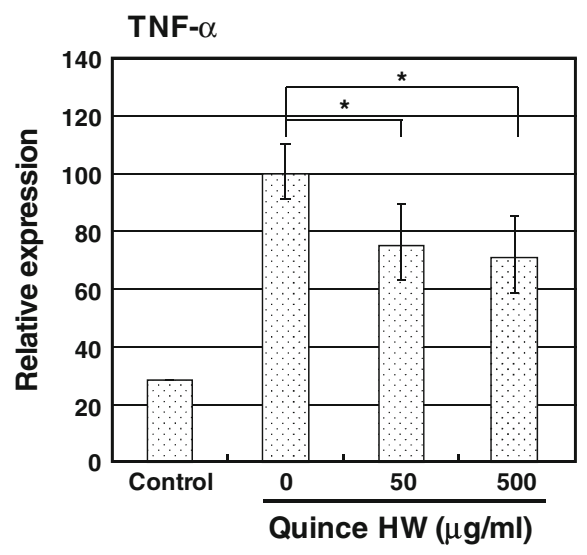

value \pm standard deviation (SD) against the unstimulated control $(n=3)$. $* p<0.05$ and $* * p<0.01$ vs. quince HWuntreated cells 
was markedly enhanced. The expression levels were then decreased after $4 \mathrm{~h}$ of stimulation (data not shown). Treatment with quince HW reduced the expression of IL-13 and TNF- $\alpha$ in a dose-dependent manner (Fig. 1). The reduction in IL-13 and TNF- $\alpha$ expression by quince HW treatment was statistically significant $(p<0.01$ and $p<0.05$, respectively).

Effect of quince HW on histamine release from BMMCs

After cultivating bone marrow-derived cells under IL-3-supplemented condition for 5 weeks, over $98 \%$ of the floating cells were confirmed as c-Kit ${ }^{+} \mathrm{Fc} \varepsilon \mathrm{RI}^{+}$ cells (typical BMMCs) by flow cytometric analysis. On the basis of this result, the effect of quince HW on the function of BMMC was investigated.

Figure 2 shows that histamine release from BMMCs after treatment with quince HW. The histamine level of degranulation supernatant after treatment with quince HW was dose-dependently reduced (Fig. 2a). Treatment with $500 \mu \mathrm{g} / \mathrm{mL}$ of quince HW results in a statistically significant reduction in histamine release $(p<0.05)$. Under the treatment condition, quince $\mathrm{HW}$ at $500 \mu \mathrm{g} / \mathrm{mL}$ concentration had no significant effect on the growth of cells even though the treatment was extended until $72 \mathrm{~h}$ (Fig. 2b). Viability of the cells (over 99\%) was also unaffected by quince HW treatment (data not shown). In addition, after treatment with quince $\mathrm{HW}$ at 0,50 and $500 \mu \mathrm{g} / \mathrm{mL}$ for $24 \mathrm{~h}$, the ratio of $\mathrm{c}^{-\mathrm{Kit}^{+}} \mathrm{Fc}_{\mathrm{RRI}}{ }^{+}$ cells was $98.7,98.4$, and $98.2 \%$ of total cells, respectively (Fig. 2c).

Effects of quince HW on IgE-induced elevation of cytokine expressions in BMMCs

To confirm the effect of quince HW on IgE-induced IL-13 and TNF- $\alpha$ expression in normal mast cells, the relative expression levels of both cytokine expressions in BMMCs after $2 \mathrm{~h}$ of stimulation were evaluated. Treatment with quince HW dose-dependently reduced the elevation of IL-13 down to $28.0 \%$ and TNF- $\alpha$ down to $48.2 \%$ after $2 \mathrm{~h}$, compared to those of the quince HW-untreated control (Fig. 3). The reduction in IL-13 and TNF- $\alpha$ expression by $500 \mu \mathrm{g} / \mathrm{mL}$ of quince $\mathrm{HW}$ was statistically significant $(p<0.01$ for IL-13 and $p<0.05$ for TNF- $\alpha$ ).
Effect of quince HW on IgE-induced lipid mediator release from BMMCs

The effects of quince HW treatment on the release of lipid mediator from BMMCs are shown in Fig. 4. The concentration of $\mathrm{LTC}_{4}$ in degranulation supernatant harvested after $1 \mathrm{~h}$ of $\operatorname{IgE}+\mathrm{Ag}$ stimulation was increased from 12.2 to $14.5 \mathrm{ng} / \mathrm{mL}$. In the presence of quince $\mathrm{HW}$, the increment was suppressed to $13.3 \mathrm{ng} /$ $\mathrm{mL}$ in a dose-dependent manner (Fig. 4a).

The concentration of $\mathrm{PGD}_{2}$ was also increased in response to the stimulation with $\operatorname{IgE}+\mathrm{Ag}$ (Fig. 4b). No significant change in the concentration of $\mathrm{PGD}_{2}$ in the supernatant collected after $1 \mathrm{~h}$ was observed between quince $\mathrm{HW}$-treated and quince $\mathrm{HW}$-untreated cells. In contrast, the elevation of $\mathrm{PGD}_{2}$ level of the supernatant harvested after $6 \mathrm{~h}$ of stimulation was observed. Quince HW significantly $(p<0.001)$ suppressed only the elevation after $6 \mathrm{~h}$ of $\mathrm{IgE}+\mathrm{Ag}$ stimulation.

Effects of quince $\mathrm{HW}$ on IgE-dependent $\mathrm{PGD}_{2}$ production and cyclooxygenase (COX) expression of BMMCs

The effects of quince HW on the enhancement of the COX-1 and COX-2 expression are shown in Fig. 5. The expression of only COX-2 was enhanced by stimulation with $\operatorname{IgE}+\mathrm{Ag}$. After treatment with quince HW, a significant decrease was observed in COX-2 elevation in a dose-dependent manner whereas the change in COX-1 expression was negligibly small.

\section{Discussion}

In this study, we focused the effects of quince HW on the $\mathrm{IgE}+\mathrm{Ag}$-induced late-phase immune reactions of mast cell using two model cells.

Figure 1 shows the mRNA expressions of IL-13 and TNF- $\alpha$ in RBL-2H3 after treatment with and without quince HW. The expression of these cytokines was notably enhanced after $2 \mathrm{~h}$ of stimulation with $\mathrm{IgE}+\mathrm{Ag}$ and diminished after $4 \mathrm{~h}$ (data not shown). Throughout the period, quince HW suppressed the elevation of these cytokine expression after $2 \mathrm{~h}$ of stimulation. As reported by Shinomiya et al. (2009), treatment with quince $\mathrm{HW}$ at a concentration of up to 
Fig. 2 Effects of quince HW on histamine release, growth, and phenotype of BMMCs. a Histamine concentration in degranulation supernatant of BMMCs after

stimulation with $\operatorname{IgE}+\mathrm{Ag}$. Control means no stimulus (without $\mathrm{IgE}+\mathrm{Ag}$ ). Data are represented as the mean value $\pm \mathrm{SD}(n=3)$.

$* p<0.05$ vs. quince

HW-untreated cells.

b Proliferation of BMMCs in the presence of quince HW. Cells were analyzed after treatment with and without quince HW for 0-72 h. White, gray, and black circle represents the result in the presence of 0 , 50 , and $500 \mu \mathrm{g} / \mathrm{mL}$ quince HW, respectively. Data are represented as the mean value $\pm \mathrm{SD}(n=3)$. c Cell surface expression of $\mathrm{c}$-Kit and FceRI of BMMCs.

Cells were analyzed after treatment with 0,50 , and $500 \mu \mathrm{g} / \mathrm{mL}$ quince $\mathrm{HW}$ for $24 \mathrm{~h}$. Negative control means the result after staining with isotype control antibodies (without treatment of quince HW). The numbers in the plots indicate the percentage of sorted cell population in each quadrant
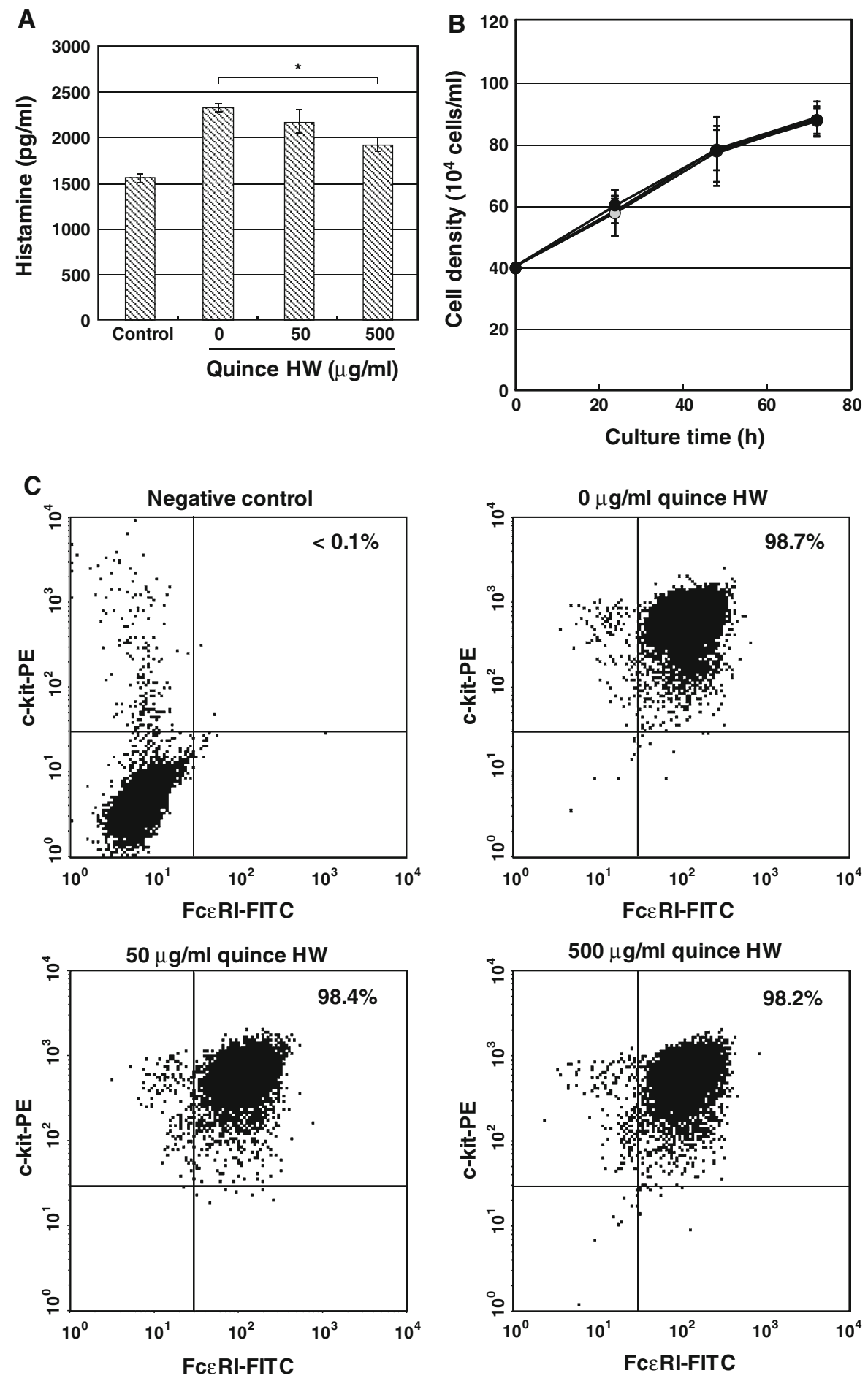

$50 \mu \mathrm{g} / \mathrm{mL}$ had no influence on growth and viability of RBL-2H3 cells.

RBL-2H3 cell is an established basophilic leukaemia cell line that is commonly used as a model of mast cells because this cell line has functional FceRI and several characteristics of IgE-dependent immune reactions (Siraganian et al. 1982; Ortega et al. 1988; Funaba et al. 2003). Our data obtained using RBL- 
Fig. 3 Effects of quince HW on cytokine expression of BMMCs. The expression of all cytokines was analyzed after $2 \mathrm{~h}$ of stimulation with $\mathrm{IgE}+\mathrm{Ag}$. Control means no stimulus (without $\mathrm{IgE}+\mathrm{Ag}$ ). Data are represented as the relative mean value $\pm \mathrm{SD}$ against the unstimulated control $(n=3)$. $* p<0.05$, $* * p<0.01$ and $* * * p<0.001$ vs. quince $\mathrm{HW}$-untreated cells
IL-13

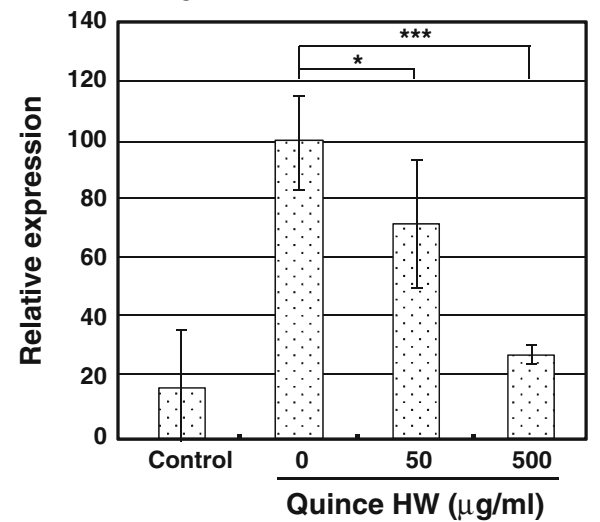

TNF- $\alpha$

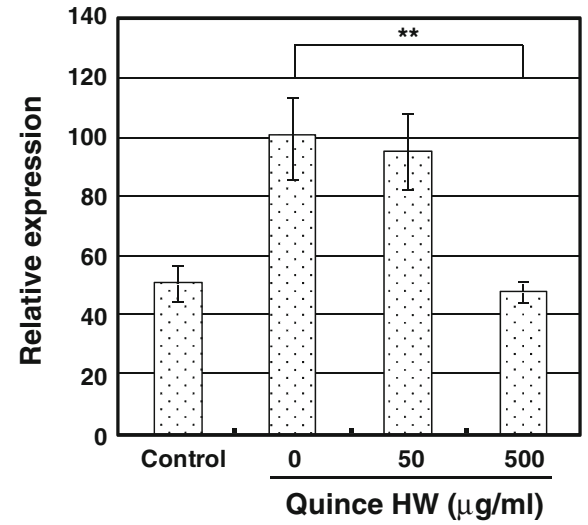

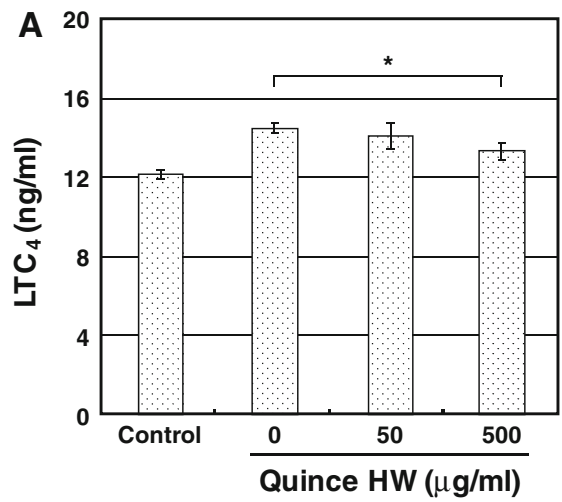

Fig. 4 Effects of quince $\mathrm{HW}$ on the production of lipid mediators in BMMCs. a $\mathrm{LTC}_{4}$ production in BMMCs after stimulation with $\mathrm{IgE}+\mathrm{Ag}$ for $2 \mathrm{~h}$. Control means no stimulus (without $\operatorname{IgE}+\mathrm{Ag}$ ). Data are represented as the relative mean value $\pm \mathrm{SD}$ against the unstimulated control $(n=3)$. ${ }^{*} p<0.05$ vs. quince $\mathrm{HW}$-untreated cells. b $\mathrm{PGD}_{2}$ production

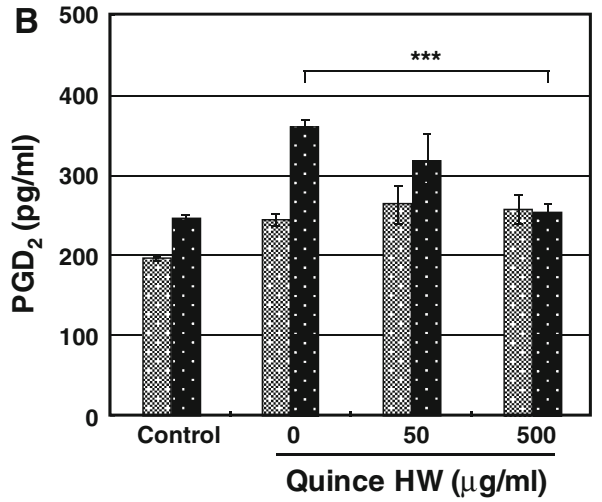

in BMMCs after stimulation with $\mathrm{IgE}+\mathrm{Ag}$ for $1 \mathrm{~h}$ (grey dotted bar) and $6 \mathrm{~h}$ (black dotted bar). Control means no stimulus (without $\operatorname{IgE}+\mathrm{Ag}$ ). Data are represented as the relative mean value $\pm \mathrm{SD}$ against the unstimulated control $(n=3)$. ${ }^{* * *} p<0.001$ vs. quince HW-untreated cells
Fig. 5 Effects of quince HW on COX-1 and COX-2 expression of BMMCs. Gene expression was analyzed after stimulation with $\operatorname{IgE}+\mathrm{Ag}$ for $2 \mathrm{~h}$. Control means no stimulus (without $\mathrm{IgE}+\mathrm{Ag}$ ). Data are represented as the relative mean value $\pm \mathrm{SD}$ against the unstimulated control $(n=3)$. $* * p<0.01$ vs. quince $\mathrm{HW}$-untreated cells

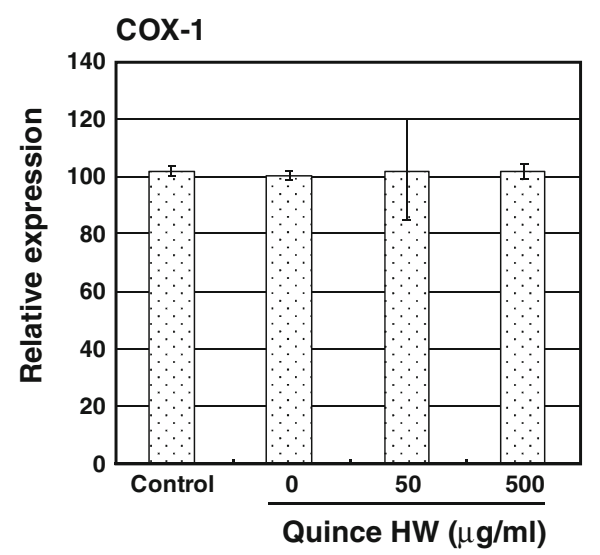

2H3 cells suggest that quince $\mathrm{HW}$ has a directly suppressive effect on IgE-dependent functions of mast cells in the absence of other immunocompetent cells. However, recent studies have focused on the abnormal susceptibility and properties of this cell line, stating that it is not fully representative of mast 
cells and basophils (Passante et al. 2009). Therefore, we further investigated the inhibitory effects of quince HW using BMMCs, which are known as a model of normal mucosal-type mast cells (Razin et al. 1981; Schrader et al. 1981).

We confirmed that quince HW suppressed histamine release from BMMCs induced by stimulation with $\operatorname{IgE}+\mathrm{Ag}$ (Fig. 2a). Treatment with quince HW even at $500 \mu \mathrm{g} / \mathrm{mL}$ showed no significant change in the proliferation and viability of BMMCs (Fig. 2b). In addition, assessment of the cell population on the basis of c-Kit and FceRI expression revealed that the subset of the BMMCs' culture was also unchanged after treatment with $0-500 \mu \mathrm{g} / \mathrm{mL}$ quince $\mathrm{HW}$ (Fig. 2c). These results suggest that quince HW has inhibitory effects on degranulation of BMMCs without affecting the viability and population of the culture. On the basis of these results, we investigated the effect of quince HW on late-phase immune reactions of BMMCs.

Figure 3 shows that quince HW significantly inhibited IgE- and Ag-induced IL-13 and TNF- $\alpha$ expression in BMMCs after $2 \mathrm{~h}$ of stimulation. In agreement with the observation in RBL-2H3 cells, the inhibitory effect of quince HW was effective on the reduction of IgE-dependent inflammatory cytokine expression in BMMCs.

BMMCs generate mainly $\mathrm{PGD}_{2}$ and $\mathrm{LTC}_{4}$ as arachidonic acid metabolites in response to the $\mathrm{IgE}$ dependent stimulation (Razin et al. 1982). We investigated the effects of quince $\mathrm{HW}$ on lipid mediator release from BMMCs. As shown in Fig. 4a, quince $\mathrm{HW}$ reduced the level of $\mathrm{LTC}_{4}$ in supernatant after $1 \mathrm{~h}$ of stimulation. $\mathrm{LTC}_{4}$ is cysteinyl leukotriene produced via arachidonic acid cascade activated by IgE-mediated stimulation. Degradation of $\mathrm{LTC}_{4}$ level suggests that quince $\mathrm{HW}$ is effective for alleviating the release of $\mathrm{LTC}_{4}$ from mast cells. In contrast, the level of the $\mathrm{PGD}_{2}$ in the degranulation supernatant collected after $1 \mathrm{~h}$ of the stimulation was unchanged by treatment with quince HW (Fig. 4b). Further analysis revealed that the $\mathrm{PGD}_{2}$ level in supernatant obtained after $6 \mathrm{~h}$ of the stimulation with $\operatorname{IgE}+\mathrm{Ag}$ was significantly lowered by quince HW treatment. $\mathrm{PGD}_{2}$ production by mast cells after stimulation with $\operatorname{IgE}+\mathrm{Ag}$ was reported to occur in two distinct phases (Murakami et al. 1994; Kawata et al. 1995). The first phase production of $\mathrm{PGD}_{2}$ is mediated by constantly expressed COX-1 using pre-released arachidonic acid within $30 \mathrm{~min}$ of stimulation. The second phase production was mediated by $\mathrm{COX}-2$, an inducible form of COX (Hundley et al. 2001), and reached its maximum $4-8 \mathrm{~h}$ after activation. In order to confirm the reason of $\mathrm{PGD}_{2}$ suppression, we investigated the effects of quince $\mathrm{HW}$ on the mRNA expression of COX-1 and COX-2. Figure 5 shows that IgE-induced COX-2 expression was significantly suppressed by quince $\mathrm{HW}$, whereas the expression of COX-1 was not affected. Therefore, the downregulation of COX-2 observed in quince $\mathrm{HW}$-treated BMMCs may in part explain the reduced second phase production of $\mathrm{PGD}_{2}$ from these cells. The inhibitors of COX used to reduce PG-derived pain and inflammatory symptoms are known as nonsteroidal anti-inflammatory drugs (NSAIDs). However, suppression of total COX by NSAIDs has been found to result in several side effects such as gastrointestinal ulcers and renal dysfunction by inhibiting physiological functions of COX-1 (Harirforoosh and Jamali 2009; Sostres et al. 2010). Therefore, selective suppression of COX-2 by quince HW is believed to be more beneficial for suppressing the induction of $\mathrm{PGD}_{2}$. We confirmed the basal expression of COX-1 and COX-2 was unchanged by quince HW treatment (data not shown). Therefore, the suppressive effect of quince $\mathrm{HW}$ on the elevation of COX-2 expression may be useful for weakening the allergic symptoms caused by $\mathrm{PGD}_{2}$.

Quince fruit has been reported to contain lowmolecular-weight polyphenols such as 3-caffeoylquinic acids (chlorogenic acid) and 5-caffeoylquinic acids (Silva et al. 2004). Recently, 3-caffeoylquinic acids were reported to alleviate mast cell-dependent anaphylactic reaction induced by $\operatorname{IgE}+\mathrm{Ag}$ (Qin et al. 2010). However, the effect of some of these polyphenols contained in quince fruit on late-phase reactions of mast cells has not been fully understood. Elucidation of the inhibitory substance in quince HW against late-phase reaction of mast cells is expected.

Taken together, we analyzed the effect of quince HW on late-phase immune reactions of mast cells using in vitro model. Considering the role of inflammatory cytokines and lipid mediators, reduced latephase immune reaction of mast cells provides possible explanation for suppressive effect of quince HW on allergic symptoms. Further study is desired for applying quince HW as a functional food to alleviate type I allergy. 
Acknowledgments This research was partly supported by a grant from the Shinshu Foundation for Promotion of Agricultural and Forest Science. I would like to express my sincere gratitude to Professor Hajime Otani, Laboratory of Food Bioscience, Faculty of Agriculture, Shinshu University, for providing me the opportunity to study in his laboratory. This work was also technically supported by the Collaborated Research Center for Food Functions, Faculty of Agriculture, Shinshu University (CREFAS) and the Research Center for Human and Environmental Sciences Division of Instrumental Analysis, Shinshu University.

\section{References}

Burd PR, Thompson WC, Max EE, Mills FC (1995) Activated mast cells produce interleukin 13. J Exp Med 181:1373-1380

Cameron L, Hamid Q, Wright E, Nakamura Y, Christodoulopoulos P, Muro S, Frenkiel S, Lavigne F, Durham S, Gould H (2000) Local synthesis of epsilon germline gene transcripts, IL-4, and IL-13 in allergic nasal mucosa after ex vivo allergen exposure. J Allergy Clin Immunol 106:46-52

Dahlén SE, Björk J, Hedqvist P, Arfors KE, Hammarström S, Lindgren JA, Samuelsson B (1981) Leukotrienes promote plasma leakage and leukocyte adhesion in postcapillary venules: in vivo effects with relevance to the acute inflammatory response. Proc Natl Acad Sci USA 78:3887-3891

Dahlén SE, Hansson G, Hedqvist P, Björck T, Granström E, Dahlén B (1983) Allergen challenge of lung tissue from asthmatics elicits bronchial contraction that correlates with the release of leukotrienes $\mathrm{C}_{4}, \mathrm{D}_{4}$, and $\mathrm{E}_{4}$. Proc Natl Acad Sci USA 80:1712-1716

Funaba M, Ikeda T, Abe M (2003) Degranulation in RBL-2H3 cells: regulation by calmodulin pathway. Cell Biol Int 27:879-885

Giles H, Leff P (1988) The biology and pharmacology of $\mathrm{PGD}_{2}$. Prostaglandins 35:277-300

Gordon JR, Galli SJ (1990) Mast cells as a source of both preformed and immunologically inducible TNF-alpha/ cachectin. Nature 346:274-276

Gordon JR, Galli SJ (1991) Release of both preformed and newly synthesized tumor necrosis factor alpha (TNF- $\alpha$ )/ cachectin by mouse mast cells stimulated via the FceRI. A mechanism for the sustained action of mast cell-derived TNF- $\alpha$ during IgE-dependent biological responses. J Exp Med 174:103-107

Harirforoosh S, Jamali F (2009) Renal adverse effects of nonsteroidal anti-inflammatory drugs. Expert Opin Drug Saf 8:669-681

Hundley TR, Prasad AR, Beaven MA (2001) Elevated levels of cyclooxygenase- 2 in antigen-stimulated mast cells is associated with minimal activation of p38 mitogen-activated protein kinase. J Immunol 167:1629-1636

Kang NI, Kim HK, Ko HM, Kim JH, You HJ, Choi IW, Im SY, Lee HK (2008) Tumor necrosis factor-alpha develops late anaphylactic reaction through cytosolic phospholipase A(2) activation. Int Arch Allergy Immunol 147:315-322
Kawata R, Reddy ST, Wolner B, Herschman HR (1995) Prostaglandin synthase 1 and prostaglandin synthase 2 both participate in activation-induced prostaglandin $\mathrm{D}_{2}$ production in mast cells. J Immunol 155:818-825

Lee E, Yook J, Haa K, Chang HW (2005) Induction of Ym1/2 in mouse bone marrow-derived mast cells by IL-4 and identification of $\mathrm{Ym} 1 / 2$ in connective tissue type-like mast cells derived from bone marrow cells cultured with IL-4 and stem cell factor. Immunol Cell Biol 83:468474

Metz M, Grimbaldeston MA, Nakae S, Piliponsky AM, Tsai M, Galli SJ (2007) Mast cells in the promotion and limitation of chronic inflammation. Immunol Rev 217:304-328

Metzger H (1978) The IgE-mast cell system as a paradigm for the study of antibody mechanisms. Immunol Rev 41:186199

Murakami M, Matsumoto R, Austen KF, Arm JP (1994) Prostaglandin endoperoxide synthase-1 and -2 couple to different transmembrane stimuli to generate prostaglandin $\mathrm{D}_{2}$ in mouse bone marrow-derived mast cells. J Biol Chem 269:22269-22275

Ortega E, Schweitzer-Stenner R, Pecht I (1988) Possible orientational constraints determine secretory signals induced by aggregation of $\mathrm{IgE}$ receptors on mast cells. EMBO J 7:4101-4109

Passante E, Ehrhardt C, Sheridan H, Frankish N (2009) RBL$2 \mathrm{H} 3$ cells are an imprecise model for mast cell mediator release. Inflamm Res 58:611-618

Pawankar R, Yamagishi S, Takizawa R, Yagi T (2003) Mast cell-IgE-and mast cell-structural cell interactions in allergic airway disease. Curr Drug Targets Inflamm Allergy 2:303-312

Qin HD, Shi YQ, Liu ZH, Li ZG, Wang HS, Wang H, Liu ZP (2010) Effect of chlorogenic acid on mast cell-dependent anaphylactic reaction. Int Immunopharmacol 10:11351141

Razin E, Cordon-Cardo C, Good RA (1981) Growth of a pure population of mouse mast cells in vitro with conditioned medium derived from concanavalin A-stimulated splenocytes. Proc Natl Acad Sci USA 78:2559-2561

Razin E, Mencia-Huerta JM, Lewis RA, Corey EJ, Austen KF (1982) Generation of leukotriene C4 from a subclass of mast cells differentiated in vitro from mouse bone marrow. Proc Natl Acad Sci USA 79:4665-4667

Schrader JW, Lewis SJ, Clark-Lewis I, Culvenor JG (1981) The persisting $(\mathrm{P})$ cell: histamine content, regulation by a $\mathrm{T}$ cell-derived factor, origin from a bone marrow precursor, and relationship to mast cells. Proc Natl Acad Sci USA 78:323-327

Seeds MC, Bass DA (1999) Regulation and metabolism of arachidonic acid. Clin Rev Allergy Immunol 17:5-26

Shinomiya F, Hamauzu Y, Kawahara T (2009) Anti-allergic effect of a hot-water extract of quince (Cydonia oblonga). Biosci Biotechnol Biochem 73:1773-1778

Silva BM, Andrade PB, Valentão P, Ferreres F, Seabra RM, Ferreira MA (2004) Quince (Cydonia oblonga Miller) fruit (pulp, peel, and seed) and Jam: antioxidant activity. J Agric Food Chem 52:4705-4712

Siraganian RP, McGivney A, Barsumian EL, Crews FT, Hirata F, Axelrod J (1982) Variants of the rat basophilic 
leukemia cell line for the study of histamine release. Fed Proc 41:30-34

Sostres C, Gargallo CJ, Arroyo MT, Lanas A (2010) Adverse effects of non-steroidal anti-inflammatory drugs (NSAIDs, aspirin and coxibs) on upper gastrointestinal tract. Best Pract Res Clin Gastroenterol 24:121-132
Stone KD, Prussin C, Metcalfe DD (2010) IgE, mast cells, basophils, and eosinophils. J Allergy Clin Immunol 125:S73-S80

Williams CM, Galli SJ (2000) The diverse potential effecter and immunoregulatory roles of mast cells in allergic disease. J Allergy Clin Immunol 105:847-859 